\title{
Acute partial Budd-Chiari syndrome and portal vein thrombosis in cytomegalovirus primary infection: a case report Laurent Spahr*1, Andreas Cerny ${ }^{2,4}$, Isabelle Morard1, Laura Rubbia-Brandt ${ }^{3}$ and Jacques Schrenzel ${ }^{2,4}$
}

\author{
Address: ${ }^{1}$ Gastroenterology and Hepatology, Ospedale Regionale, Lugano, Switzerland, ${ }^{2}$ Servicio di Medicina Interna, Ospedale Regionale, \\ Lugano, Switzerland, ${ }^{3}$ Clinical Pathology, University Hospital, Geneva, Switzerland and ${ }^{4}$ Infectious Diseases, University Hospital, Geneva, \\ Switzerland \\ Email: Laurent Spahr* - Laurent.Spahr@hcuge.ch; Andreas Cerny - andreas.cerny@bluewin.ch; Isabelle Morard - Isabelle.Morard@hcuge.ch; \\ Laura Rubbia-Brandt - rubbia-brandt-laura@diogenes.hcuge.ch; Jacques Schrenzel - jacques.schrenzel@hcuge.ch \\ * Corresponding author
}

Published: 10 March 2006

BMC Gastroenterology2006, 6:10 doi:10.1 186/1471-230X-6-10

Received: 13 October 2005

Accepted: 10 March 2006

This article is available from: http://www.biomedcentral.com/I47I-230X/6/10

(C) 2006Spahr et al; licensee BioMed Central Ltd.

This is an Open Access article distributed under the terms of the Creative Commons Attribution License (http://creativecommons.org/licenses/by/2.0), which permits unrestricted use, distribution, and reproduction in any medium, provided the original work is properly cited.

\begin{abstract}
Background: Splanchnic vein thrombosis may complicate inherited thrombotic disorders. Acute cytomegalovirus infection is a rare cause of acquired venous thrombosis in the portal or mesenteric territory, but has never been described extending into a main hepatic vein.

Case presentation: A 36-year-old immunocompetent woman presented with acute primary cytomegalovirus infection in association with extensive thrombosis in the portal and splenic vein. In addition, a fresh thrombus was evident in the right hepatic vein. A thorough evaluation for a hypercoagulable state was negative. The clinical course, biological evolution, radiological and histological findings were consistent with cytomegalovirus hepatitis complicated by a partial acute Budd-Chiari syndrome and portal thrombosis. Therapeutic anticoagulation was associated with a slow clinical improvement and partial vascular recanalization.

Conclusion: We described in details a new association between cytomegalovirus infection and acute venous thrombosis both in the portal vein and in the right hepatic vein, realizing a partial Budd-Chiari syndrome. One should be aware that this rare thrombotic event may be complicated by partial venous outflow block.
\end{abstract}

\section{Background}

The development of venous thrombosis has been occasionally reported in the setting of acute cytomegalovirus infection in immunocompetent adults, possibly as a result of a procoagulant effect on endothelial cells. Such a vascular event may take place in the splanchnic territory (portal and mesenteric vein), but has never been described in the hepatic veins.
Hepatic vein obstruction is associated to a clinical and pathological presentation named the Budd-Chiari syndrome, including hepatic sinusoidal dilatation and congestion, ascites and abdominal pain, as a result of hepatic outflow block. Hepatic vein thrombosis, typically associated to primary myeloproliferative disorders, has never been described in association with an acute infection. We provide here a detailed observation of a partial acute Budd-Chiari syndrome complicating an acute cytomegalovirus infection. 

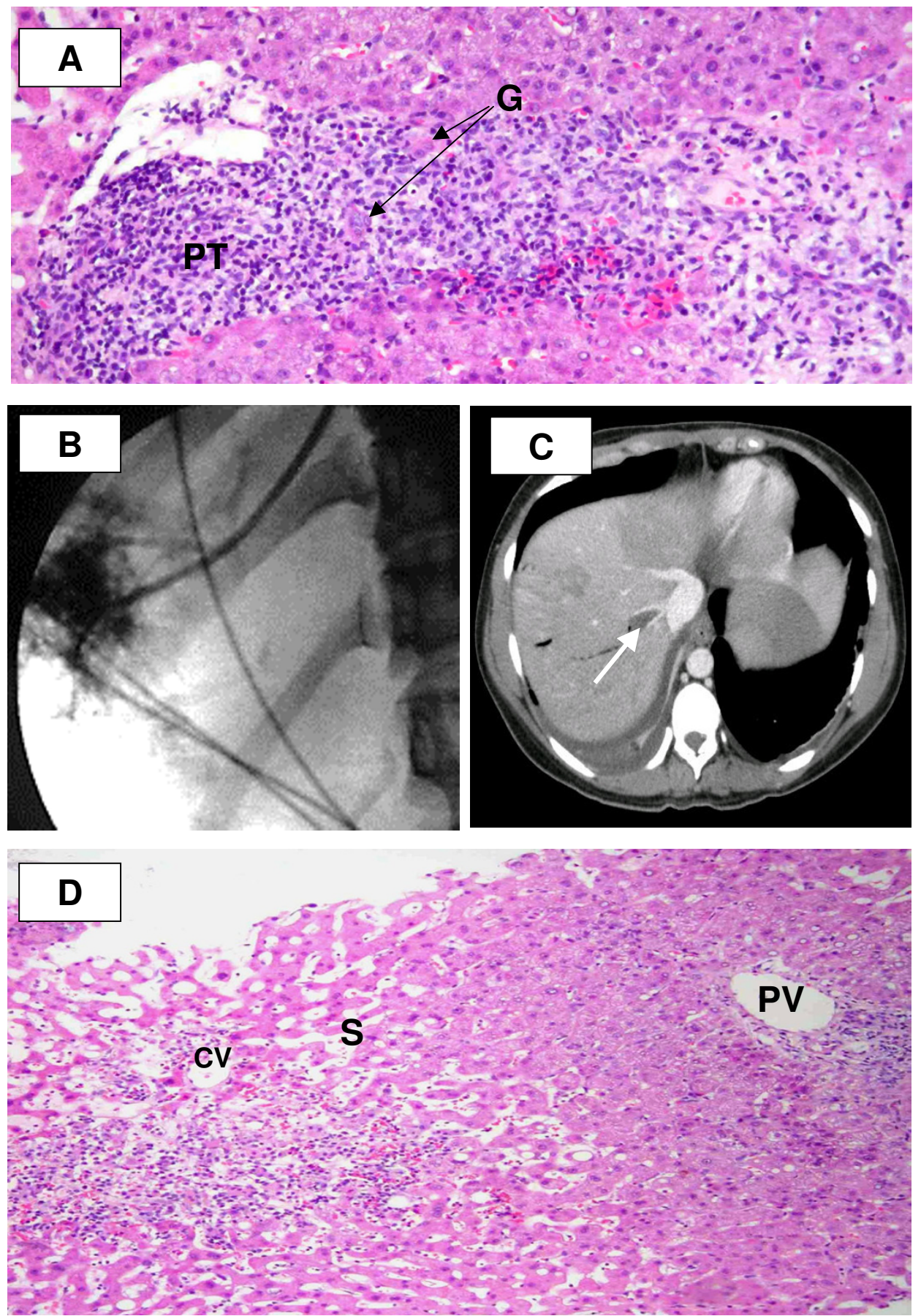

\section{Figure I}

Panel A: Low magnification of the liver biopsy (HE I20 x). The portal tract (PT) is infiltrated by a mixed inflammatory reaction. Microgranulomatous cell reaction $(G)$ is visible. Panel B: Typical "spider-web" network pattern at hepatic angiography in the setting of partial Budd-Chiari syndrome. Panel C: Abdominal CT scan showing a fresh thrombus in the ostium of the right hepatic vein (arrow). Panel D: Low magnification of liver biopsy showing marked sinusoidal dilatation (S) and congestion around the central vein (CV). PV: portal vein. 


\section{Case presentation}

A 36-year-old woman presented with abdominal pain and fever $\left(38.5-39^{\circ} \mathrm{C}\right)$ of 3 weeks duration. She was previously healthy, and was on oral oestroprogestative since one year. Two years ago, CMV IgG tested negative. Leukocyte count was 9700 cells $/ \mathrm{mm}^{3}$, platelets were 80000/ $\mathrm{mm}^{3}$, and C-reactive protein level was $110 \mathrm{mg} / \mathrm{L}(\mathrm{N}$ : < 10). ALT level was $49 \mathrm{U} / \mathrm{L}(\mathrm{N}:<37)$, AST was $45 \mathrm{U} / \mathrm{L}(\mathrm{N}$ : <36), $\gamma$-glutamyltranspeptidase level was 49 (N: < 36), with normal LDH, alkaline phosphatase, bilirubin and INR values. Haptoglobin value was $2.06 \mathrm{~g} / \mathrm{l}(\mathrm{N}$ : $0.28-$ 1.78). Prothrombin time and fibrinogen level were normal. An abdominal CT scan showed an enlarged spleen and a thrombus in the splenic vein extending into the portal trunk. A fresh thrombus was also evident in the right hepatic vein (see figure). A thorough evaluation for a hypercoagulable state was performed: homocystein level: $6.7 \mu \mathrm{mol} / \mathrm{l}(\mathrm{N}:<15)$; antithrombin III: $86 \%$ (N: 75-125); protein C: $74 \%$ (N: $70-140)$; protein S: $88 \%$ (N: $50-120)$; factor V Leiden and prothrombin 20210 genes: not mutated; anticardiolipin antibodies: negative; antinuclear antibodies: < 1/60; paroxysmal nocturnal hemoglobinuria: absence of deficience of GPI-linked proteins by flow cytometry. Although a bone marrow analysis was not performed, an overt myeloproliferative disorder was deemed unlikely in the absence of grossly elevated white blood cells and platelet count, no eosinophilia, basophilia, or atypical platelet morphology on the peripheral smear examination. We felt that the probability of an early hepatocellular carcinoma in the absence of a pre-existing liver disease was extremely low. The value of AFP was $4 \mathrm{ng} / \mathrm{ml}$ $(\mathrm{N}<15 \mathrm{ng} / \mathrm{ml})$

Blood cultures remained sterile, and serological tests for hepatitis A, B, C and HIV were negative. Serum immunoglobulins were as follows: IgG: $19 \mathrm{~g} / \mathrm{l}(\mathrm{N}$ : 6.7-13); IgA: $4.3 \mathrm{~g} / \mathrm{l}(\mathrm{N}: 0.7-2.9)$; IgM: 2.6 (N: 0.4-2.6). Typisation of circulating lymphocytes $(\mathrm{T}, \mathrm{B}, \mathrm{NK})$ showed normal values.

Serological testing for CMV showed elevated titers of IgG and IgM. CMV DNA using real-time PCR was detectable at a level of 5 copies per $10^{6}$, with a partial inhibition of amplification. EBV DNA was negative. Mild duodenal inflammation was observed at endoscopy, with viral-type inclusions visible in endothelial cells seen in intestinal biopsy.

Intravenous heparin at a therapeutic level was administered, and oral contraception was stopped. The patient remained febrile (temperature $39^{\circ} \mathrm{C}$ ), and the abdominal pain increased in intensity despite full-dose anticoagulation. The AST and ALT levels increased (76 U/L and 111 $\mathrm{U} / \mathrm{L}$, respectively). A repeat abdominal CT scan showed moderate ascites. Using a transjugular approach, direct venography was performed after a difficult cannulation of the right hepatic vein, demonstrating a "spider-web" network pattern typically seen in Budd-Chiari syndrome (see figure). The hepatic venous pressure gradient showed moderate portal hypertension, with a value of $9 \mathrm{mmHg}$ $(\mathrm{N}:<4)$. Liver histology (see figure) showed acute hepatitis with a mononuclear and neutrophilic infiltrate, scattered areas of hepatocyte necrosis, and a microgranulomatous cell reaction. An immunohistochemistry study was performed on the liver biopsy specimen to detect CMV[1], but remained negative. There were no features of a pre-existing liver disease, and no lesions (plasma cells infiltration, interface hepatitis) that may suggest the presence of auto-immune hepatitis[2]. In addition, a marked sinusoidal dilatation and congestion in the centrilobular regions were consistent with a hepatic vein outflow obstruction[3].

Five days after liver biopsy, transaminases returned to normal values. The patient remained febrile with mild abdominal pain persisting another 3 weeks. At 5 months, control ultrasonography showed persistently obstructed right hepatic, splenic and portal vein with a cavernoma, but no ascites.

\section{Conclusion}

Splanchnic thrombosis in association with acute CMV infection is a very rare event in an immunocompetent host[4]. It has been reported in the portal or mesenteric territory [5-7] and in extra abdominal vascular beds[8], sometimes associated with an underlying prothrombotic state. We describe here a detailed case of acute CMV infection with typical microgranulomatous hepatitis and splanchnic thrombosis, and report for the first time the development of an acute thrombosis in a main hepatic vein consistent with a partial Budd-Chiari syndrome.

Cytomegalovirus infection in an immunocompetent host may occur in childhood or in young adulthood, and often follows an asymptomatic course. In an immunocompromized patient, this important viral pathogen may induce serious complications including colitis, esophagitis or pneumonitis[9]. In this young immunocompetent female adult, the diagnosis of acute CMV primary infection was established on a positive viremia and a typical acute microgranulomatous hepatitis[10]. Clinical features included a severe mononucleosis-like syndrome and an acute thrombosis in the splenic, portal and right hepatic vein. Although fatal issues have been reported in severe cytomegalovirus infection in such individuals[4], we decided not to administer ganciclovir to our patient in the view of a relatively modest viral load, preserved white blood cell count and absence of detectable CMV on livr biopsy. Accordingly, antiviral treatment is not routinely recommended in immunocompetent individuals with severe CMV infection[4]. 
The radiological evidence of hepatic vein thrombosis, an enlarged liver, an increased abdominal pain, congestion around the central vein of the liver lobule at histology, elevated portal pressure, raised serum aminotransferases and presence of ascites rendered the diagnosis of partial BuddChiari syndrome most likely[11]. Due to the limited extent of the hepatic venous thrombosis, clinical and biological alterations were limited in intensity[3]. Thus, thrombolysis or mechanical angioplasty were not considered in the present case.

Although splanchnic vein thrombosis may result from a combination of several factors, it is currently indicated to search for an underlying hypercoagulable disorder[11]. In our patient, we did not identify a coagulation disorder, but we hypothesized that the acute CMV infection combined with oral contraceptives precipitated the acute and extensive vascular thrombosis. In vitro, $\mathrm{CMV}$ infection induces a procoagulant state by altering endothelial cell surface[12]. The alteration in the endothelium phenotype that includes overexpressed surface adhesion molecules[13] stimulates leucocytes and platelets adhesion[14] and results in an increased procoagulant activity[15]. Thus, a number of observations point towards a damage to vascular endothelium in the presence of $\mathrm{CMV}$, and supports the hypothesis that acute CMV infection increases the risk of thrombosis.

In conclusion, CMV primary infection, i) should be considered in the diagnostic work-up of acute splanchnic vein thrombosis, and ii) may be associated to a partial BuddChiari syndrome.

\section{Abbreviations \\ $\mathrm{CMV}$ : cytomegalovirus infection}

\section{Competing interests}

The author(s) declare that they have no competing interests.

\section{Authors' contributions}

L.S. performed the invasive procedure, and wrote and discussed the case report

I.M: coordinated the coagulation work-up and clinical follow-up

L.R-B: performed the histopathological analysis

J.S: coordinated the virological studies

\section{References}

I. Colina F, Juca NT, Moreno E, Ballestin C, Farina J, Nevado M, Lumbreras C, Gomez-Sanz R: Histological diagnosis of cytomegalovirus hepatitis in liver allografts. J Clin Pathol 1995, 48(4):35I-357.

2. Alvarez F, Berg PA, Bianchi FB, Bianchi L, Burroughs AK, Cancado EL, Chapman RW, Cooksley WG, Czaja AJ, Desmet VJ, Donaldson PT, Eddleston AL, Fainboim L, Heathcote J, Homberg JC, Hoofnagle JH, Kakumu S, Krawitt EL, Mackay IR, MacSween RN, Maddrey WC, Manns MP, McFarlane IG, Meyer zum Buschenfelde KH, Zeniya M, et al.: International Autoimmune Hepatitis Group Report: review of criteria for diagnosis of autoimmune hepatitis. J Hepatol 1999, 3 I(5):929-938.

3. Bogin V, Marcos A, Shaw-Stiffel T: Budd-Chiari syndrome: in evolution. Eur J Gastroenterol Hepatol 2005, 17(I):33-35.

4. Eddleston M, Peacock S, Juniper M, Warrell DA: Severe cytomegalovirus infection in immunocompetent patients. Clin Infect Dis 1997, 24(I):52-56.

5. Abgueguen P, Delbos V, Chennebault JM, Payan C, Pichard E: Vascular thrombosis and acute cytomegalovirus infection in immunocompetent patients: report of 2 cases and literature review. Clin Infect Dis 2003, 36(I I):EI 34-9.

6. Benoist S, Laisne MJ, Joly F, Boudiaf M, Panis Y, Valleur P: Cytomegalovirus infection as a cause of acute superior mesenteric vein thrombosis with jejunal infarction. Surgery 2003, 133(2):222-223.

7. Inacio C, Hillaire S, Valla D, Denninger MH, Casadevall N, Erlinger S: Case report: cytomegalovirus infection as a cause of acute portal vein thrombosis. J Gastroenterol Hepatol 1997, I 2(4):287-288

8. Bauduer F, Blanc A, Cordon B: Deep vein thrombosis and acute cytomegalovirus infection: case report and review of the literature. Blood Coagul Fibrinolysis 2003, I 4(5):489-49I.

9. Rowshani AT, Bemelman FJ, van Leeuwen EM, van Lier RA, ten Berge IJ: Clinical and immunologic aspects of cytomegalovirus infection in solid organ transplant recipients. Transplantation 2005, 79(4):38I-386.

10. Bentata-Pessayre M, Beaugrand M, Callard P, Brun-Vesinet F, Krivitsky A, Mornet P, Delzant G: [Granulomatous hepatitis in cytomegalovirus infection in healthy adults]. Ann Med Interne (Paris) 1987, I38(5):353-357.

II. Valla DC: Hepatic vein thrombosis (Budd-Chiari syndrome). Semin Liver Dis 2002, 22(I):5- 14.

12. van Dam-Mieras MC, Muller AD, van Hinsbergh VW, Mullers WJ, Bomans PH, Bruggeman CA: The procoagulant response of cytomegalovirus infected endothelial cells. Thromb Haemost 1992, 68(3):364-370.

13. Cebulla CM, Miller DM, Knight DA, Briggs BR, McGaughy V, Sedmak DD: Cytomegalovirus induces sialyl Lewis $(x)$ and Lewis( $(x)$ on human endothelial cells. Transplantation 2000, 69(6): I $202-1209$.

14. Span AH, van Dam-Mieras MC, Mullers W, Endert J, Muller AD, Bruggeman CA: The effect of virus infection on the adherence of leukocytes or platelets to endothelial cells. Eur J Clin Invest |99|, 2 | (3):33|-338.

15. Vercellotti GM: Effects of viral activation of the vessel wall on inflammation and thrombosis. Blood Coagul Fibrinolysis 1998, 9 Suppl 2:S3-6.

\section{Pre-publication history}

The pre-publication history for this paper can be accessed here:

http://www.biomedcentral.com/1471-230X/6/10/pre pub

\section{Acknowledgements}

None 